\title{
FAKTOR PENYEBAB KONFLIK PEMILIHAN KEPALA DESA SERENTAK DI KABUPATEN HALMAHERA SELATAN
}

\author{
FACTORS CAUSING THE CONFLICT OF SELECTION OF THE \\ SIMULTANEOUS VILLAGE HEAD IN SOUTH HALMAHERA DISTRICT \\ Marno Wance1, Abd Halil Hi Ibrahim ${ }^{2}$ \\ 1 Universitas Pattimura, Indonesia \\ 2Universitas Muhammadiyah Maluku Utara, Indonesia \\ E-mail: marno.wance@fisip.unpati.ac.id
}

\begin{abstract}
Simultaneous village head elections in 2016 held in South Halmahera Regency ended up with conflicts. There were 249 villages spread across 32 sub-districts participating in the village head elections. The simultaneous village head elections were divided into two phases in which the first one was held on 20 November 2018 taken by 189 villages. While 60 villages were held in the second phase. The first election left 16 cases of conflicts. The fact in the field revealed that the conflicts occured because there were some complaints coming from the losing candidates that the election organizers had taken side on one of the candidates and their supporting team which had closeness to the regional leader. Besides, there were some actors intervening in the election that caused conflicts among candidates. Considering the facts, this research was conducted in two villages with the aim of comparing the conflicts in the villages and the resolution models. The research method used was descriptive qualitative by conducting in-depth interviews with parties involved in the election conflicts.
\end{abstract}

Keywords: Head Village Election; Election Conflict; Village Democracy

ABSTRACT

Pemilihan kepala desa serentak tahun 2016 yang dilaksanakan di Kabupaten Halmahera Selatan menyisahkan konflik Pilkades. Adapun desa yang mengikuti kontetasi pemilihan kepala desa (Pilkades) serentak berjumlah 249 desa yang tersebar di 32 kecamatan. Pilkades serentak terbagi menjadi dua tahap yaitu tahap pertama yang dilaksanakan pada tanggal 20 November 2018 yang diikuti oleh 189 desa. Sedangkan 60 desa akan dilaksanakan pada tahap kedua. Pelaksanaaan Pilkades tahap pertama mengalami konflik Pilkades di 16 desa. Penyebabnya karena penyelenggara di tingkat desa berpihak kepala salah satu kandidat, tim tim sukses kandidat, dan kedekatan dengan penguasa daerah. Selainitu, konflik Pilkades terjadi karena aktor-aktor daerah melakukan intervensi pada proses pemilihan sehingga mengakibatkan konflik antara kandidat. Penelitian konflik Pilkades di Halmahera Selatan dilakukan pada dua desa dengan

Journal of Governance and Local Politics (JGLP)

ISSN (online): 2684-9992, Vol. 1, No. 2, November 2019 
tujuan untuk membandingkan penyebab konflik dan model penyelesain konflik Pilkades. Metode penelitian yang digunakan yaitu deskriptif kualitatif dengan cara melakukan wawancara secara mendalam dengan pihak-pihak yang terlibat pada konflik Pilkades di Halmahera Selatan.

\section{Keywords: Pilkades; Konflik Pemilihan; Demokrasi Desa}

\section{PENDAHULUAN}

Demokrasi dalam konteks pemilihan Kepala Desa (Pilkades) dapat dipahami sebagai pengakuan keanekaragaman serta sikap politik partisipasif dari masyarakat dalam bingkai demokratisasi pada tingkat desa. Runtuhnya masa Orde Baru dan hadirnya liberalisasi politik membawa perubahan bagi kondisi sosial dan politik mulai dari tingkat lokal. Liberalisasi politik membuka ruang bagi setiap individu untuk turut serta berpartisipasi di panggung politik pemerintahan, baik tingkal lokal hingga nasional. Hal ini memberikan angin segar bagi kalangan yang selama ini terpinggirkan karena status sosial (Razak \& Harakan, 2017). Pilkades merupakan salah satu kegiatan politik yang menarik bagi masyarakat desa. Pilkades di Indonesia saat ini masih penuh dengan ironisme. Di satu sisi, rakyat yang sangat apatis dan tidak peduli sehingga tingkat partisipatif masyarakat dalam Pilkades menurun. Apatisme masyarakat ini justru dimanfaatkan oleh orang-orang tertentu untuk meraih jabatan dan kekayaan dengan memanfaatkan kekuasaan politik. Mereka adalah para elit desa yang ingin melanggengkan kekayaan dan kekuasaan agar tetap jatuh kepada garis keluarga. Sehingga fakta menunjukan keberadaan calon kepala desa masih didominasi oleh segelintir orang yang berkuasa di desa.

Sengketa yang paling banyak terjadi dalam konflik saat pemilihan kepala desa adalah permasalahan adanya dugaan manipulasi hasil rekapitulasi perhitungan suara. Sengketa lainnya menyorot masalah perilaku pemilih, baik yang tidak terdaftar yang diklaim sebagai pemilih potensial, tudingan politik uang juga menjadi isu yang banyak diangkat tim sukses yang kalah dalam 
bersaing. Pemilihan Kepala Desa yang sering disingkat dengan Pilkades mungkin bukan istilah yang asing lagi untuk saat ini. Sebagai wadah untuk menampung aspirasi politik masyarakat sekaligus sarana pergantian atau kelanjutan pemerintahan desa. Pilkades diharapkan mampu memenuhi keinginan dan harapan masyarakat desa tertentu, untuk mengangkat calon yang layak sebagai kepala desa.

Pilkades merupakan sebuah instrumen dalam pembentukan pemerintahan modern dan demokratis. Pesta demokrasi yang dilakukan di tingkat wilayah terkecil ini pada dasarnya sudah diatur oleh peraturan perundang-undangan pemerintah tentang tata cara penyelenggaraan Pilkades. Sehingga seluruh rangkaian tahapan-tahapannya mulai dari pembentukan panitia Pilkades sampai pada pelantikan kepala desa terpilih diharapkan sesuai dengan ketentuan yang sudah ditetapkan. Dengan demikian proses pemilihan kepala desa akan berjalan dengan baik tanpa mempengaruhi keutuhan masyarakat. Harapan masyarakat dapat terpenuhi untuk terpilihnya kepala desa yang baru dan dinyatakan layak untuk memimpin dan menjalankan roda pemerintahan desa. Hal inilah yang didambakan oleh setiap masyarakat desa demi terciptanya keadaan yang kondusif. Namun dalam praktiknya Pilkades yang sudah diatur oleh perundangundangan pemerintah untuk saat ini sangat sulit terselenggara dengan lancar dan berkualitas karena bermainnya faktor-faktor kepentingan politik, kepentingan untuk ingin berebut kekuasaan daripada hakikat yang diinginkansaatpelaksanaan Pilkades adalah pemerintahan desa yang legitimate.

Saat penyelenggaraan pemilihan kepala desa di Kabupaten Halmahera Selatan tidak lepas dari budaya yang dimiliki oleh daerah tersebut. Di mana, masyarakat Halmahera Selatan adalah komunitas masyarakat yang heterogen. Hal tersebut dikarenakan, di Halmahera Selatan terdapat beragam suku, pemeluk agama, yakni Islam, Kristen Katolik, Prostestan. Namun, meskipun terdapat keseragaman dalam hal agama dan etnis, dalam masalah sosial, konflik 
kerap kali terjadi dan sebagai contoh dalam pemilihan kepala desa secara serentak ini, terjadi kericuhan yang mengakibatkan konflik yang serius. Di dalam penyelenggaraan pesta demokrasi ini terdapat banyak masalah dan persoalan sebagai gejala awal konflik yang diwarnai dengan kericuhan, kekerasan, yang dapat merusak keutuhan dan eksistensi masyarakatnya.

Konflik Pilkades secara serentak yang dilakukan di Kabupaten Halmahera Selatan juga mengalami permasalahan sengketa Pilkades. Konflik terjadi disebabkan oleh permainan elit daerah, kelompok kepentingan yang menggunakan kekuatan-kekuatan politik sarat kewenangan yang dimiliki untuk memperkuat basis, jaringan di tingkat desa. Proses pemilihan kepala desa secara serentak di Kabupaten Halmahera Selatan telah selesai sejak Desember 2016 lalu. Bahkan sebagian kepala desa terpilih kini telah dilantik. Proses demokrasi yang berlangsung di desa itu memiliki hiruk-pikuk dan magnet tersendiri di kalangan masyarakat desa di Halmahera Selatan. Pasalnya prosesnya ternyata hingga kini masih meninggakan bara konflik. Banyak persoalan yang tersisa dan sekali-sekali akan meletup menjadi konflik antar masyarakat. Betapa tidak saat ini akibat dari konflik Pilkades itu, ada bahkan warga yang terusir dari kampungnya karena kalah Pilkades. Bahkan panitia Pilkades dihakimi hingga nyaris tewas. Dinamika konflik bahkan ada yang memalang Kantor Camat hingga berhari hari. Warna-warni konflik dan kekerasan ini menjadi bunga rampai proses Pilkades di Kabupaten paling selatan Halmahera 2016.

Selain itu, pada beberapa kasus konflik pemilihan kepala yaitu (Istifarin, 2016) kekerasan Pilkades, (Halifa, 2016) politik dinasti pada Pilkades, (Suwardi, 2015)tentang politik uang, sedekah politik, (Zerunisa \& Winarni, 2017) political marketing Pilkades yang digunakan untuk memenangkan pemilihan kepala desa, (Wance \& Suranto, 2016) pola interaksi kekuasaan yang terjadi tawar menawar (barganing) untuk melakukan pertukaran kepentingan. Pada riset ini lebih melihat tentang fenomena gelombang pemilihan kepala desa serentak 
mengakibatkan intervesi oleh para kelompok kekuasaan yang memiliki kekuasaan serta kewenangan. Ada beberapa teori yang digunakan untuk menganalisis kuasa politik yang terjadi di lokus pemilihan kepala desa di Maluku Utara. Hasil penelitian yang dilakukan oleh Wance, Djae (2019) menyimpulkan bahwa pelaksanaan pilakdes serentak 2016 dapat mencapai tujuan akhir, yakni terpilihnya kepala desa melalui proses Pilakdes secara langsung. Walapun banyak berakhir dengan proses hukum pelanggaran pemilu. Pilkades serentak 2016 di Kabupaten Halmahera Selatan sebagai besar terjadi konflik dan diselesaikan melaui proses PTUN di Ambon. Hasil putusan pengeadilan konflik Pilkades dimenangkan oleh pemerintah Kabupaten Halmahera Selatan. Dominasi kekuasaan penyelenggara di Desa Babang yaitu keperpihakan penyelenggara Pilkades serta masih mempunyai hubungan darah/keluaraga dengan salah satu pasangan.

\section{METODE PENELITIAN}

Jenis Penelitian ini menggunakan pendekatan penelitian Deskriptif kualitatif yaitu ada beberapa definisi mengenai pendekatan ini (Moleong, 2007). Penelitian ini dilaksanakan pada dua Desa yang berkonflik pada pemilihan kepala desa serentak 2016 di Kabupaten Halmahera Selatan yaitu Desa Babang dan Desa Marabose. Alasan memilih dua lokasi ini karena dua desa memiliki model konflik yang berbeda. Model konflik yang berbeda untuk menjadi perbandingan melihat faktor konflik Pilkades yang terjadi di Halmahera Selatan. Pengambilan data dilakukan secara langsung dengan wawancara baik secara terstruktur dan tidak terstruktur.

Metode yang digunakan dalam penelitian ini diharapkan mampu mengungkapkan fenomena peristiwa faktual yang terjadi di lapangan bahkan mampu menyajikan dan mengungkapkan nilai-nilai yang tersembunyi dari penelitian ini. Di mana objek penelitian yang akan diteliti tentang bagaimana mendeskripsikan 
"Faktor penyebab konflik pemilihan kepala desa serentak 2016 di Kabupaten Halmahera Selatan".

Penelitian ini dilakukan di beberapa desa di Kabupaten Halmahera Selatan yang terjadi sengketa pemilihan kepada desa. lokasi penelitian dengan pertimbangan-pertimbangan bahwa konflik pemilihan kepala desa yang terjadi di Kabupaten Halmahera Selatan tahun 2016 dengan studi kasus perbandingan pada dua desa yaitu Desa Babang dan Marabose, sedangkan penelitian dilakukan pada bulan April 2018. Sehingga dalam proses penetapan calon kepala desa terpilih terjadi konflik karena ada beberapa calon kepala desa terpilih yang tidak di tetapkan menjadi kepala desa. Maka pada objek permasalahan ini peneliti mencoba untuk mendeskripsikan dan mengkaji lebih jauh bagaimana Relasi kekuatan politik lokal pada konflik pemilihan kepala desa di Kabupaten Halmahera Selatan Tahun 2016. Maka dalam melakukan proses pemilihan kepala desa sesuai dengan tahapan-tahapan serta menghindari konfigurasi kekuatan politik lokal karena dapat mengakibatkan pada mencedrai nilai-nilai demokrasi di tingkat desa.

\section{HASIL DAN PEMBAHASAN}

\section{Faktor Konflik Pemilihan Kepala Desa}

Pemilihan kepala desa serentak tahun 2016 yang dilakukan di Kabupaten Halmahera Selatan sangat identik dengan rumusan yang diajukan oleh Lasswell berupa who gets, what, when, how (Harold, 1936). Definisi bernuansa pragmatis tersebut melekat dalam kesadaran, baik level elit maupun massa Akibat, prosesproses politik yang berlangsung selalu saja bermuara pada transaksikompensasional yang bersifat material (uang). Menjadi makin eksplisit ketika mencermati praktik lazim jual-beli suara pada saat Pemilu. Padahal Pemilu merupakan pintu masuk minimal untuk mengukur seberapa besar kualitas demokrasi yang dapat dijalankan. 
Dalam konteks demikian, menggeser spirit kuasa politik untuk kembali mendominasi kekuasaan yang lebih besar lagi. Dominasi politik hendaknya dimurnikan menjadi upaya-upaya menciptakan kewenanngan kekuasaan di tingkat bawah yaitu desa. Caranya? Tentu tidak cukup hanya meneriakkan usaha dominasi kekuasaan, dengan cara membangun relasi kuasa politik sejak awal sehingga pemilihan serentak yang dilakukan merupakan momentum untuk membangun jejaring, relasi struktu pada tingkat pemerintahan desa.

Politik tak lagi memadai ketika hanya didistorsikan menjadi perebutan kekuasaan material karena hanya akan mereproduksi sederet masalah yang membentuk lingkaran setan. Di sinilah pentingnya pilihan-pilihan rasional diajukan. Artinya, proses-proses politik yang berlangsung sejak hulu (Pemilu maupun Pilkades serentak) hingga hilir (implementasi dan evaluasi kebijakan) haruslah bertumpu pada pertimbangan-pertimbangan rasional. Pertimbangan rasional secara sederhana merujuk pada filsafat utilitarian sebagai maximizing profits, minimizing risks bagi seluas-luas masyarakat.

Sementara itu, kebijakan baru tentang partai politik yakni sistem multi partai di awal masa transisi mengakhiri sistem kepartian dengan tiga partai politik yang selama Orde Baru berkuasa. Hal ini yang kemudian memberikan alternatif lebih bagi pemilih Indonesia serta politisi untuk memilih partai politik yang sesuai aspirasi maupun kepentingan mereka. Namun, kebijakan pemilihan kepala desa serentak ini telah menempatkan perebutan kekuasaan yang bersaing dalam posisi dilematis. Dominasi kekuasaan harus memilih antara memperoleh banyak orang sebagai relasi atau memperkuat institusi jaringan kekuasaan. Ternyata, sebagian besar interest group (kelompok kepentingan) tampaknya lebih tertarik untuk mendapatkan dominasi kekuasan yang loyal dari pada membangun institusi pemerintah desa yang kuat. Ada dua implikasi penting dari situasi ini. 
1. Personal branding memainkan peran yang lebih berpengaruh dalam mememangkan kontestasi pemilihan kepala desa di Kabupaten Halmahera Selatan. Ini yang kemudian diterjemahkan ke dalam dominasi kekuasaan yang lebih rendah oleh pemilih, seperti yang ditandai dengan tingginya jumlah kesadaran politik dan kelembagaan dalam pemilu.

2. Transaksional kepentingan hubungan antara kandidat yang bertarung pada pemilihan kepala desa serentak tahun 2016 dengan yang kelompokkelompok kepentingan yang memegang kewenangan kekuasaan, sehingga pemilihan kepala desa tidak lagi didasarkan pada loyalitas atau kinerja, namun lebih kepada hubungan transaksional. Dominasi kuasa politik pada pemilihan calon kandidat dan mekanisme promosi relatif longgar. Popularitas seseorang/kandidat sekarang menjadi dasar untuk mencalonkan kandidat dalam pemilihan kepala desa serentak tahun 2016. Kombinasi dari pemilihan kepala desa secara langsung dan sistem pemilihan serentak secara bersama sama memberikan peluang untuk elit lokal dalam memperkuat basis kekuasaan ke depan. Sayangnya, beberapa elite lokal berasal atau dibangun dari hubungan sedarah, kekerabatan dan keluarga yang sama.

Konflik pemilihan kepala desa (Pilkades) yang terjadi di Kabupaten Halmahera Selatan memicu perlawananan dari masyarakat untuk mendapatkan distribusi keadilan pemilihan kepala desa secara adil dan kepastian hukum. Perlawanan hukum pemilun dilakukan secara terbuka, antara lain melakukan demostrasi di kantor bupati, menduduki areal pemerintah pemerintah desa setempat dan perkalihan secara fisik. Semua dilakukan untuk mematahkan dominasi kekuasaan pemerintah atas proses pemilihan kepala desa demi mendapatkan keadilan pemilih dan kepastian hukum yang jelas. Berbagai kasus konflik pemilihan kepala desa serentak tahap I mengungkapkan perebutan arena kekuasaan. Sehingga kemudian memicu munculnya konflik kekuasaan 
antara pemerintah untuk mempertahankan arena kekuasaan di tingkat pemerintah desa.

Berdasarkan pada kajian kasus terkait dengan masalah-masalah yang muncul pada pelaksanaan pemilihan kepala desa serentak tahun 2016 di Kabupaten Halmahera Selatan. Pelaksanaan pemilihan kepala desa secara langsung yang berkaitan dengan erat dengan kematangan perencanaan sampai pada pelaksanaan pemilihan oleh rakyat harus dipastikan hak semua orang yang memilih bisa diakomodir. Ada beberapa fakor yang menyebabkan konflik pemilihan kepala desa serentak di tahun 2016 yaitu sebagai berikut:

1. Faktor menjadi sumber masalah pada pemilihan kepala (Pilkades) desa serentak pada tahap I adalah lemahnya administrasi penyelenggara Administrasi Pilkdes langsung yang kurang baik menyebabkan sengketa hasil Pilkades. Sejumlah urusan administrasi misalnya pendataan penduduk, pemutakhiran data calon pemilih. Akibatnya proses pemilhan berlangsung sebagaimana mestinya.

2. Proses sosialisasi pelaksanaan Pilkades serentak tahun 2016 di Kabupaten Halmahera Selatan yang tidak memadai sehingga mengakibatkan timbulnya konflik pasca Pilkades. Sehingga, sosialiasi Pilkades mesti diadakan karena menjadi tumpuan utama dalam mensukseskan salah bentuk demokrasi lokal di tingkat desa tersebut. Selain itu, dalam proses sosialisasi juga perlu ditekankan satu cara dalam mendidik masyarakat berpolitik secara kritis serta kadidat kepala desa (kades) juga bisa menerima hasil dari pilihan rakyat secara kolektif. Oleh sebab itu, Pilkades langsung memberikan kesempatan kepada rakyat untuk memilih kepala daerah secara langsung sehingga rakyat dapat menggunakan hak pilih secara cerdas dengan pertimbangan kritis-rasional berasas pada visi dan program kerja. (Wawancara Irawan Samsudin ,2018) 


\section{Hubungan Calon Kepala Desa dengan Kekuasaan}

Distribusi kekuasaan memiliki dampak keterpilihan yang sangat signifikan, khususnya pada pemilihan kepala desa serentak tahun 2016. Dominasi konflik di kabupaten Halmahera Selatan cukup tinggi, gejala konflik ini tidak lepas dari terbentuk pragmatisme pemilih pada pemilihan bupati pada tahun 2015. Dominasi pada pemilihan kepala desa menuntut untuk menekan suara pada kelompok tertentu, sebagian kandidat calon kepala desa harus beradaptasi terhadap kompelksitas persaingan dominasi kuasa politik yang terbentuk sejak pemilihan bupati 2015. Jaringan tim sukses, relasi pemenangan yang membuat elit lokal yang berkuasa ingin mendominasi kekuasaan di desa sebagai bentuk membangun kekuatan politik serta dominasi kekuasaan yang lebih massif dan terorganisasir untuk kepentingan politik ke depan. Maka perbandingan jumlah konflik Pilkades serentak 2016 di Kabupaten Halmahera Selatan sangat minim yaitu berdasarkan pada tabel berikut:

\section{Grafik 1.}

Perbandingan Konflik Pilkades Tahap 1

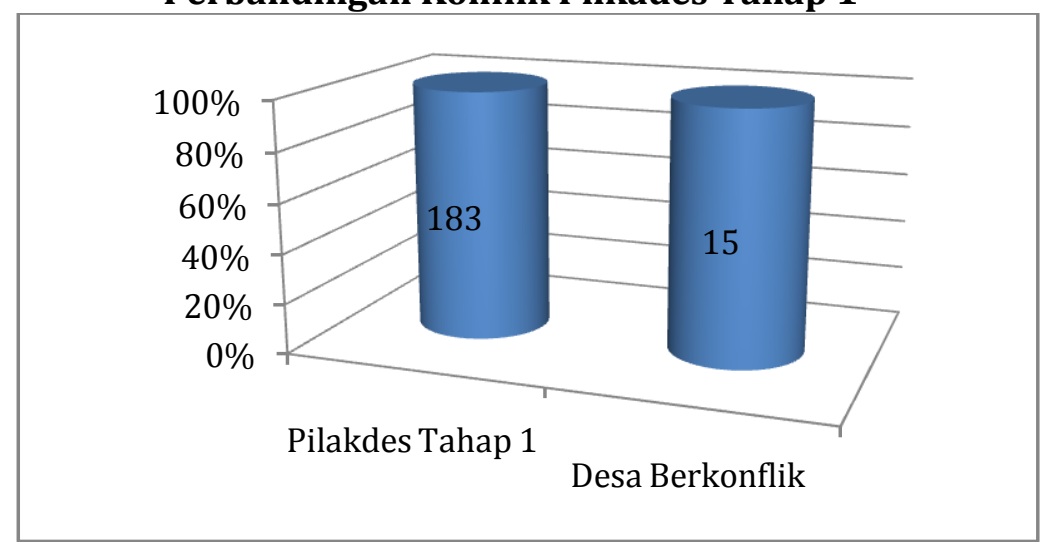

Sumber: Data Diolah, 2018

Berbasarkan grafik 1 perbadingan desa yang berkonflik pada pemilihan kepala desa serentak merupakan bangunan jaringan kelompok kekuasaan, relasi tim serta kepentingan kelompok tertentu, selain itu ada juga hubungan calon kepala desa dengan kekuasaan persaudaraan. Satu suku akan memberikan 
dukungan supaya terpilih menjadi kepala desa pada pemilihan kepala desa serentak 2016. Dalam hal ini, ada dua faktor yang muncul, mengingat di Kabupaten Halmahera Selatan ada dua suku besar yang mendominasi kekuasaan. Walaupun bukan menjadi faktor penentu dominasi kekuasaan namun sangat menentukan dan menjadi faktor kuat yakni, pertama adalah reputasi pribadi individu kandidat, yakni integritas, pencapaian seorang figur publik, dan aktivitas sosial. Faktor kedua adalah dukungan masyarakat atau organisasi.

Desa yang mengikuti pemilihan kepala desa pada pemilihan kepala desa serentak tahap I tahun 2016 berjumlah 183 Desa yang tersebar di 32 Kecamatan. Dari jumlah desa yang mengikuti pemilihan kepala desa tahap 1, ada 15 desa yang berkonflik pemilihan kepala desa. Penyelesain konflik pemilihan kepala desa serentak 2016 dalam dua bentuk yaitu pertama, penyelesaian konflik Pilkades oleh Pemerintah Halmahera Selatan. Kedua penyelesain konflik melalui sidang PTUN Ambon.

Tabel1.

Model Penyelesain Konflik

\begin{tabular}{|l|l|l|}
\hline No & \multicolumn{1}{|c|}{ Nama Desa } & \multicolumn{1}{|c|}{ Keterangan } \\
\hline 1 & $\begin{array}{l}\text { Desa Gala, Desa Tawabi, Desa Bisori, } \\
\text { Desa Geti Lama, Desa Waya, Desa } \\
\text { Matuting Tanjung, Desa Babang, Desa } \\
\text { Ake Gula }\end{array}$ & $\begin{array}{l}\text { Tim Penyelesaian } \\
\text { Konflik Pilkades } \\
\text { Serentak Tahap I }\end{array}$ \\
\hline 2 & $\begin{array}{l}\text { Desa Pulau Gala, Desa Marabose, Desa } \\
\text { Bori, Desa Wayaua }\end{array}$ & PTUN Ambon \\
\hline
\end{tabular}

Sumber: Hasil analisis data penelitian,2018

Berdasarkan pada tabel 1 di atas, bahwa ada dua bentuk penyelesain konflik pemilihan kepala desa. Pendekatan menyesuaikan dilakukan oleh pihakpihak yang terlibat konflik dalam artian calon kepala desa pada Pilkades serentak yang dengan cara salah satu pihak melepaskan atau mengesampingkan keinginan kelompoknya dan memenuhi keinginan pihak lain. Melalui 
pendekatan ini pihak yang satu merelakan kebutuhannya, sehingga pihak lain mendapatkan sepenuhnya yang diinginkan.

Seiring berjalannya waktu pasca pemilihan kepala desa serentak $2016 \mathrm{di}$ Kabupaten Halmahera Selatan terlihat bahwa di antara beberapa calon atau kandidat yang kalah di pertarungan secara perlahan telah menerima kekalahan dan tentunya itu semua tidak lepas dari kerjasama antara pemerintah setempat, Tokoh-tokoh masyarakat serta jajaran Pemerintah Kecamatan dan Pemerintah Daerah yang selalu beruaha untuk melakukan pendekatan kepada pihak-pihak yang kontra atas keputusan yang di keluarkan oleh lembaga pemungutan suara pemilihan Kepala Desa. Kemudian jika keputusan yang diambil ada pihak tertentu merasa dirugikan maka proses hukum sangat terbuka untuk dilakukan banding melalui PTUN di Ambon

Perbandingan kemenangan pada pemilihan kepala desa serentak merupakan bangunan jaringan kelompok kekuasaan relasi tim serta kepentingan kelompok tertentu, selain itu ada juga hubungan calon kepala desa dengan kekuasaan persaudaraan. Satu suku akan memberikan dukungan supaya terpilih menjadi kepala desa pada pemilihan kepala desa serentak 2016. Dalam hal ini, ada dua faktor yang muncul, mengingat di Kabupaten Halmahera Selatan ada dua suku besar yang mendominasi kekuasaan. Walaupun bukan menjadi faktor penentu dominasi kekuasaan namun sangat menentukan dan menjadi faktor kuat yakni, pertama adalah reputasi pribadi individu kandidat, yakni integritas, pencapaian seorang figur publik, dan aktivitas sosial. Faktor kedua adalah dukungan masyarakat atau organisasi.

Sementara itu, dominasi kekuasaan pada pemilihan kepala desa di Babang pada tahun 2018. Praktek kekuasaan untuk mendominasi jaringan pemerintah desa dengan mengusung salah satu kader Partai Keadilan Sejahtera (PKS) yaitu calon kades Ahmad Haji Abu pada pemilihan Bupati Halmahera Selatan menjadi tim sukses Bupati Terpilih Bahrain Kasuba. Hubungan M. Sofyan Aswin dengan 
kekuasaan sehingga pada pemilihan kepala desa serentak 2016 terjadi intervensi kekuasaan. Pada pemilihan kepala desa Babang Sofyan Aswin Abu memperoleh suara terbanyak urutan kedua (530 suara) yang menjadi pemenang Pilkades Babang 2016 Irawan Hi Samsudi (610 suara). Namun pada sengketa pada tingkat pemerintah daerah Halmahera Selatan calon kepala desa Ahmad Haji Abu menjadi pemenang sengketa. yaitu sebagai berikut:

Berdasarkan pada tabel 1 di atas bahwa pemilihan kepala desa Babang tahun 2016 di ikuti oleh pasangan kandidat yang mempunyai tingkat pendidikan sama. Pada pemilihan serentak 2016, Adapun jumlah Daftar Pemilih Tetap (DPT) yaitu sebanyak 2.744.000 orang, yang menggunakan hak pilih 1.600 .022 orang. DPT Ini diambil berdasarkan pada rekap pemilih pada pemilihan bupati tahun 2015. sebanyak Desa yang terjadi konflik pemilihan kepala Desa di Halmaheara Selatan salah satunya juga Desa babang. Dalam kasus ini, ada beberapa faktor sehingga terjadi konflik Pilkade 2016 (Wawancara dengan Soleman Retop, 2018).

Tim monitoring dari pemerintah yaitu kepala Badan Pemberdayaan Masyarakat Desa (BPMD) Kabupaten Halmahera Selatan yang melihat proses pemilihan kepala desa serentak di Babang. Namun karena dari BPMD melakukan monitoring di desa lain sehingga tidak memantau proses sampai selesai rekapitalasi sampai penantangan berita acara.

Konflik kekuasaan di Desa Babang melibatkan melibatkan kelompok kepentingan untuk menyelesaikan kandidat dan tidak berbadasarkan pada proses pemilihan.Argumentasi tersebut sehingga membuat pasangan lain untuk melakukan gugatan ke PTUN Ambon untuk mencari keadilan pemilu di Kabupaten Halmahera Selatan.

Konflik pemilihan kepala desa serentak tahun 2016 di Kabupaten Halmahera Selatan, penolakan hasil putusan hasil pemilihan kepala desa (Pilkades) dengan menggelar aksi protes di kantor Bupati, terdiri dari Warga 
Halsel dari 5 (lima) desa Marabose, Babang, Wayaua, Bori, dan desa Silang. Pemasalahan dan konflik terjadi di beberapa desa seperti desa Bori, Babang dan Marabose paska Pilkades karena adanya putusan SK Bupati Nomor: 286 tahun 2016 tentang pembentukan tim penyelesesaian perselisihan Pilkades serentak Kabupaten Halmahera Selatan. Dimana SK tersebut, dinilai illegal karena tidak sesuai dengan Perda Nomor 7 Tahun 2015, Peraturan Bupati Nomor 8 Tahun 2016, UU No 6 Tahun 2014, Permendagri 112 Tahun 2014. Maka dengan begitu, Hasil Sengketa Pilkades desa Babang yang diputuskan oleh Majelis/Tim penyelesaian perselisihan hasil Pilkades Serentak Kabupaten Halmahera Selatan dimana Ahmad H. Abu (Calon Kades No. Urut 4) dalam pungutan dan penghitungan suara memperoleh 565 suara sebagai pemenang kedua sedangkan Irwan Samsudin (Calon No. Urut 2) memperoleh 604 suara sebagai pemenang pertama. Namun, dalam putusan hasil sengketa oleh Tim penyelesaian perselisihan Pilkades Ahmad H. Abu kemudian ditetapkan sebagai Calon Kades terpilih desa Babang, hasil putusan tersebut diduga ada muatan politik dan cacat hukum karena perolehan suara Calon Kades No. Urut 2 Irwan Samsudin adalah murni pilihan masyarakat desa Babang (www.wartamalut.com)

Sementara itu, proses pelantikan akan ditindaklanjuti oleh pemerintah Kabupaten Halmahera Selatan setalah ada putusan yang bersifat mengikat dan tetap untuk dijalankan oleh calon kades pada Pilkades serentak 2016. Dalam hal ini, ada dari desakan dari anggota DPRD Kabupaten Halmahera Selatan Akmal Ibrahim kepada Bupati Bahrain Kasuba segera melantik kepala desa (Kades) terpilih 10 desa yang tertunda karena dianggap bermasalah. Menurut Akmal, janji Pemda Halsel melalui Dinas PMD bahwa kapala desa 10 desa yang belum dilantik akan diproses setelah sengketa hasil Pilkades lima desa di PTUN Ambon. Sedangkan dari lima desa yang menggugat Pemda Halmahera Selatan di PTUN Ambon sudah ada putusan dan dimenangkan pihak pemerintah daerah Halmahera Selatan (www.taliabuposonline.com). 


\section{Gambar 1}

\section{Model Akar Permasalahan Pilakdes Serentak 2016}

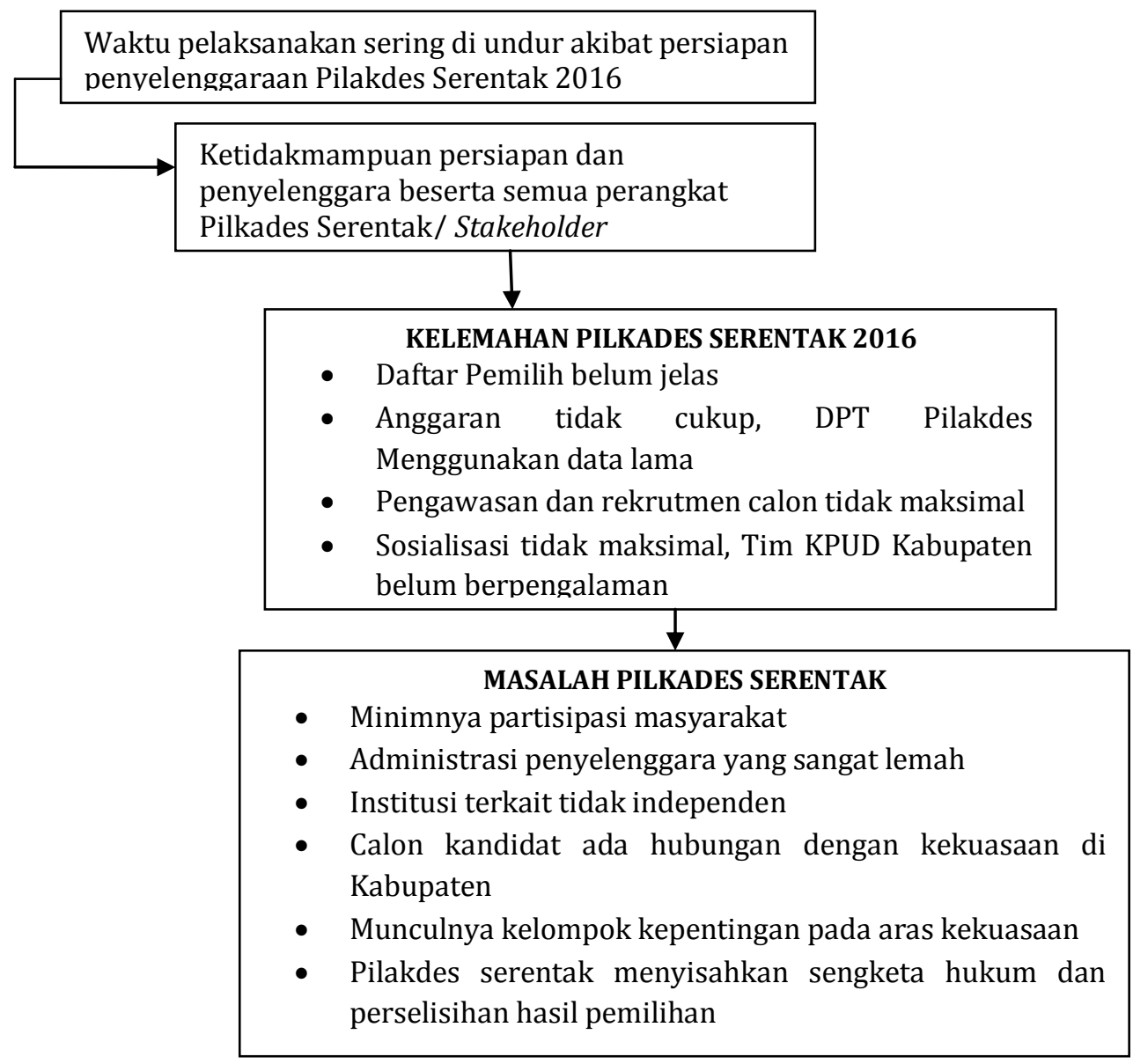

Sumber: diolah penulis

\section{Menyesuaikan (accomoding)}

Pendekatan menyesuaikan di lakukan oleh pihak-pihak yang terlibat konflik dalam artian calon Kepala Desa pada Pilkades serentak yang dengan cara salah satu pihak melepaskan atau mengesampingkan keinginan kelompoknya dan memenuhi keinginan pihak lain. Melalui pendekatan ini pihak yang satu merelakan kebutuhannya, sehingga pihak lain mendapatkan sepenuhnya yang diinginkan.

Seiring berjalannya waktu pasca pemilihan Kepala Desa serentak 2016 di Kabupaten Halmahera Selatan terlihat bahwa di antara beberapa calon atau kandidat 
yang kalah di pertarungan secara perlahan telah menerima kekalahan dan tentunya itu semua tidak lepas dari kerjasama antara pemerintah setempat, Tokoh-tokoh masyarakat serta jajaran Pemerintah Kecamatan dan Pemerintah Daerah yang selalu beruaha untuk melakukan pendekatan kepada pihak-pihak yang kontra atas keputusan yang di keluarkan oleh lembaga pemungutan suara pemilihan Kepala Desa. Kemudian jika keputusan yang diambil ada pihak tertentu merasa dirugikan maka proses hukum sangat terbuka untuk dilakukan banding melalui PTUN di ambon.

\section{KESIMPULAN}

Penyebab konflik pemilihan kepala desa di Kabupaten Halmahera Selatan serentak 2016 yaitu pertama panitia pemilihan kepada serentak belum melakukan pemutahiran data pemilih yang baru sehingga menyebabkan data pemilih semakin ganda, kebanyakan pemilih sudah meninggal. Jumlah pemilih yang sedikit di tingkat desa sehingga masyarakat saling mengenal antara satu pemilih dengan pemilih serta dapat melakukan pengawasan yang ketat di antara sesama kandidat. Kedua kandidat yang bertarung pada pemilihan kepala desa serentak ada hubungannya dengan pemerintah kabupaten sehingga mengakibatkan penyelenggara tidak netral dalam melakukan pemilihan di tingkat desa. Sehingga hadirnya aktor-aktor politik lokal yang berkepentingan untuk memenangkan kandidat. Ketiga penyelesaian konflik pemilihan kepala desa di Kabupaten Halmahera Selatan melalui dua tahapan yaitu penyelesaian di tingkat pemerintah daerah melalui BPMD yang mengundang desa-desa yang berkonflik, tahap kedua pihak-pihak yang merasa dirugikan dalam pemilihan kepala desa menempuh jalur penyelesaian di PTUN Ambon.

\section{REFERENSI}

Aron, R. (1965). Main Currents In Sociological Thought II. New York: Howard R. dan Weaver H., Anchor. 
Cahyono, H. (2005). Konflik Elit Politik Pedesaan. Jakarta: Pustaka Pelajar.

Collins, R. (1975). Conflict Sociology. New York: New York Academic Press.

Eddy Kiswanto. (2014). Pemilihan Kepala Desa; Implementasi Peraturan Daerah di Kecamatan Rembang. Tesis Universitas Diponegoro .

Galtung, J. (2004). Kekerasan, Perdamaian, dan Penelitian Perdamaian . Jurnal Pemberdayaan .

Halifa, N. (2016). Politik Dinasti: Studi Kasus Kemenangan Dinasti Samidin Dalam Pilkades di Desa Banjar Kec. Kedungdung Kab. Sampang. Diss. Uin sunan Ampel surabaya, 2016. Dis.Uin Sunan Ampel .

Harold, D. L. (1936). Politics: Who Gets What, When, How, Ny: . Amaerika Serikat: hittlesey House.

Hidayat, I. (2009). Teori-Teori Politik. Malang: SETARA press.

HR, F. S., \& Harakan, A. (2017). Eksklusivitas Adat Dalam Bingkai Demokrasi Di Indonesia. Jurnal Agregasi, 14-25.

Istifarin. (2016). Fenomena Politik Kekerasan dalam Pilkades di Desa Ketapang Laok Kecamatan Ketapang Kabupaten Sampang Madura. Diss. Uin sunan ampel Surabaya. . Diss. Uin Sunan Ampel .

J.E.T., E. (1980). Max Weber The Interpretation of Social Reality. New York: Schocken Books New York.

Kusnad. (2002). Konflik Sosial Nelayan. LKIS Jakarta. Jakarta: LKIS.

Moleong. (2007). Metodologi Penelitian Kualitatif . Bandung: PT Remaja Rosda Karya.

Razak, \& Harakan, A. (2017). Eksklusivitas Adat Dalam Bingkai Demokrasi Di Indonesia. Jurnal Agregasi , 14-25.

Sanit, A. (1997). Partai, Pemilu dan Demokrasi. Yogyakarta: Pustaka Pelajar.

Setiadi, E. M., \& Kolib, U. (2015). PENGANTAR SOSIOLOGI, Pemahaman Fakta dan Gejala Permasalahan Sosial: Teori, Aplikasi, dan Pemecahannya. Jakarta: PRENADAMEDIA GROUP. 
Suwardi. (2015). Politik Uang Dalam Pemilihan Kepala Desa tahun 2014: Studi Tentang Pemahaman Masyarakat Terhadap Politik Uang di Desa Poreh Kecamatan Lenteng Kabupaten Sumenep. Diss. Uin sunan ampel Surabaya. digibli.uinsby .

Turner, J. (1991). The Structure of Sociological Theory. California: Wardworth Publising Company California.

Wance, M. \&. (2019). Dominasi Kuasa pada Pemilihan Kepala Desa Serentak di Kabupaten Halmahera Selatan Provinsi Maluku Utara. ARISTO , 204-227.

Zerunisa, R., \& Winarni, F. (2017). Political Marketing Kandidat Dalam Pemilihan Kepala Desa (Pilkades) (Studi Kasus Desa Getan Kecamatan Gantiwarno Kabupaten Klaten). Jurnal Student, 100-104.

http://kabarpulau.com/berita-konflik-Pilkades-di-halsel-cukup-memiriskan-.html. diakses pada Rabu 31 Mei 2017)

https://regional.kompas.com/read/2016/11/12/12450391/pemilihan.kepala.desa.ser entak.di.halmahera.selatan.polisi.siagakan.kekuatan.penuh. di akses pada Rabu 31 Desember 2017) 